\title{
ENTITAS GEREJA DALAM BERPOLITIK DI INDONESIA (TINJAUAN SUDUT ETIKA KRISTEN)
}

\author{
Oleh: Ni Nyoman Fransiska M.Th
}

Email : Fransiska.nyoman@yahoo.com

\begin{abstract}
Abstrak
This paper discusses the political attitudes of Christians towards politics in Indonesia. Christians have been actively involved in the resistance movement against the Dutch colonialists, participated in establishing the country, formulated ideology and ratified the 1945 Constitution, participated in maintaining Indonesia's independence through the war of independence and played an active role in building the Indonesian nation. The state was created by God to carry out its function of creating justice, protecting and serving society. Therefore Christians are also called to participate in the creation of Peace (Welfare) in the country, because in a prosperous and peaceful country, the church can live better (Jer.29: 7).
\end{abstract}

Tulisan ini membahas Etika umat Kristen terhadap politik di Indonesia. Umat Kristen sudah dari sejak awal terlibat aktif dalam gerakan perlawanan terhadap penjajah Belanda, turut serta dalam mendirikan negara , merumuskan Ideologi dan mengesahkan UUD 1945, ikut mempertahankan kemerdekaan Indonesia melalui perang kemerdekaan serta berperan aktif dalam membangun bangsa Indonesia. Negara diciptakan Tuhan untuk menjalankan fungsinya yaitu menciptakan keadilan, melindungi dan melayani masyarakat. Oleh karena itu umat Kristen juga terpanggil untuk ikut mengusahakan terciptanya Damai (Kesejahteraan) di dalam negara, karena dalam negara yang makmur dan damai, gereja dapat hidup lebih baik (Yer.29:7).

Kata Kunci : Gereja,Politik,Etika, hubungan gereja dan politik

\section{Pendahuluan}

Indonesia merupakan negara dengan masyarakat yang majemuk. Indonesia sendiri memiliki enam agama yang resmi, yaitu Islam, Katolik, Kristen, Hindu, Budha dan Konghucu. Selain agama yang beragama, Indonesia juga memiliki aneka ragam suku, budaya, bahasa dan lainnya. Dengan memiliki banyak perbedaan yang tercipta Indonesia dilebihkan karena memiliki persatuan dan kesatuan dimana masyarakat harus memiliki hak dan kewajiban yang sama disemua bidang, contohnya bidang politik, hukum, sosial, budaya, pendidikan dan beberapa bidang lainnya. Dewasa ini peran orang Kristen sebagai sekte minoritas di dalam perpolitikan di Indonesia masih sangat minim. Pertama: Menurut sejarah, Kekristenan di Indonesia dan Kolonialisme kebetulan datang 
dalam waktu yang bersamaan. Sehingga muncul pandangan bahwa orang-orang Kristen di Indonesia kurang Nasionalis ${ }^{1}$. Sejarah mencatat bahwa masuknya gereja di Indonesia terutama di Nusantara daerah pesisir merupakan hasil dari Zending yang dipengaruhi oleh politik Portugis dan Spanyol pada saat itu. Diperkirakan bahwa gereja hadir di Indonesia dibawa oleh bangsa Eropa sejak abad ke-16 ${ }^{2}$ Alasan inilah yang menjadikan batasan bagi umat kristen yang ingin ikut berjuang dalam politik di Indonesia. Dan pandangan ini harus dibantah karena tujuan dari Kekristenan dan Kolonialisme berbeda. Kekristenan untuk memberitakan injil sedangkan Kolonialisme untuk menguasai perdagangan di Indonesia. Umat Kristen sejak awal bersikap kritis kepada penjajah bahkan mereka pernah melakukan perlawanan bersenjata kepada penjajah seperti yang dilakukan oleh Pattimura di Maluku ${ }^{3}$ Tentu sikap intoleransi terhadap umat Kristen yang semakin menguat di bangsa ini adalah suatu kemunduran dan keprihatinan besar yang sangat mengkhawatirkan masa depan sebagai negara demokrasi.

Kedua: Di masa reformasi ini ada semakin banyak terjadi penyimpangan dalam bidang politik. Sudah menjadi rahasia umum bahwa politik sering diidentikan dengan penggunaan kuasa tanpa moral ${ }^{4}$ Jadi tidaklah mengherankan apabila banyak hal yang terjadi di dunia ini dihubungkan dengan politik. Ada begitu banyak respon dan tanggapan dari berbagai kalangan yang berbeda, termasuk menurut agama Kristen. Cukup banyak orang Kristen, termasuk mahasiswa Kristen, yang takut atau antipati terhadap politik. Hal ini terjadi akibat image negatif dari politik yang dianggap tempat iblis atau setan bermain. Adanya konsep pemikiran seperti ini timbul karena mereka tidak memahami esensi dan makna politik dengan benar. sebab mau tidak mau masyarakat, khususnya umat Kristen, pasti dihadapkan dengan masalah politik. Melalui tulisan ini Penulis ingin mendorong umat Kristen di Indonesia meningkatkan jiwa Nasionalisme sesuai dengan UUD 1945 dan jiwa Pancasila.

\section{Pengertian Etika Kristen}

Kata "Etika Kristen" berasal dari Bahasa Yunani "etos" yang memiliki arti adat istiadat dan kebiasaan. Menurut Hukum Taurat, Etika dalam Kristen adalah segala perbuatan yang dikehendaki oleh Allah untuk selalu melakukan perbuatan baik. Di dalam hidup, etika dalam Kristen bertugas untuk menyelidiki, mengoreksi, mengontrol, dan mengarahkan tentang mana yang harusnya dilakukan dan mana yang tidak boleh dilakukan. Tolak ukur untuk melakukan perbuatan baik bersumber pada titah Yesus Kristus, dimana landasan untuk berbuat baik tertuang dalam Hukum Taurat. Dari sudut perjanjian lama etika adalah anugerah Allah terhadap umatNya dan tuntunan dan

\footnotetext{
${ }^{1}$ Yewange A.A, Gereja dan Reformasi , Jakarta:Yakoma PGI, 1999 hal.157

${ }^{2}$ Borrong, Robert P. Etika Politik Kristen. (Jakarta: Unit Publikasi dan Informasi (UPI) dan Pusat Studi Etika (PSE), 2006) hal. 22

${ }^{3}$ Daulay Richard M, Agama dan Politik di Indonesia, Jakarta: BPK Gunung Mulia, 2016 hal.3

${ }^{4}$ Robert Borong, Etika Politik Kristen serba-serbi politik praktis, Jakarta:UPI dan PSE, 2006 hal 27
} 
perintahNya yang terikat pada tindakanNya demi keselamatan manusia. Berdasarkan konsep tersebut, maka dasar etika perjanjian lama dapat disorot dari empat sisi : 1. Menanggapi perbuatan Allah dimana bangsa Israel harus memiliki dorongan untuk mengarah pada kelakuan etis dalam wujud tanggap terhadap tindakan Allah dalam sejarah kehidupan mereka. 2. Mengikuti teladan Allah dimana bangsa Israel wajib memperlihatkan sifat Allah melalui tingkah laku mereka. 3. Hidup dibawah pemerintahan Allah maksudnya adalah manusia harus taat dan tunduk pada kedaulatan Allah sebagai Raja yang memerintah. 4. Menaati semua perintah Allah. Dan menurut George Wolfgang Forell menekankan bahwa, titik utama Etika Kristen, khususnya etika Perjanjian Baru) adalah Yesus Kristus. Kehidupan Kristus menjadi tema-tema pokok Perjanjian baru, menjadi pusat norma etis bagi orang yang percaya kepada-Nya. Dalam Etika Kristen kehendak Tuhan dikedepankan sehingga sifat Etika Kristen adalah teologis dan imani.

Dengan hadirnya etika kristen di dunia tentu memiliki dasar kuat dalam memberikan pencerahan dalam pengaturan tata perilaku dan norma dalam masyarakat. Hubungan antara etika Kristen dan politik dal0am Kekristenan kita adalah perbuatan yang dilakukan berdasarkan analisa akal budi dan keputusan batin akan hal yang baik dalam bidang politik agar sesuai dengan kehendak Tuhan. Dengan demikian etika Kristen dalam politik tidak berhak atau tidak berkuasa atau tidak bertugas untuk mengucapkan firman Tuhan, tetapi menjadi petunjuk yang sederhana dan mengarahkan supaya semua negara dan bangsa harus tunduk kepada Tuhan dan firman-Nya. Oleh sebab itu Etika Kristen yang dimaksudkan di sini adalah kebiasaan (way of live) menurut 2 Petrus 3:11 yang mengikat seseorang dan sekelompok orang yang berpedoman kepada sikap Kristus, yang dinyatakan melalui Alkitab sebagai firman Tuhan. Dan hakekat firman Tuhan tidak berubah (Matius 5:18; Matius 24:35), serta Kristus yang menjadi pusat penilaian Etika Kristen, yang tidak berubah (Ibrani 1:12; 13:8), menjadikan Etika Kristen itu tidak mengalami perubahan, sekalipun konteks sebuah Negara atau kota berbeda-beda, dan berubah-ubah sesuai dengan perkembangan zaman. Etika Kristen bukan hanya untuk orang Kristen dan oleh orang Kristen tetapi berlaku untuk semua manusis, masyarakat, dan semua aspek kehidupan (universal).

\section{Pandangan Alkitab Terhadap Politik}

Istilah politik tidak dijumpai secara tersurat dalam Alkitab. Alkitab tidak menulis secara sistematis mengenai masalah politik. Namun perlu disadari bahwa di dalam Alkitab tersirat bagianbagian tentang bagaimana Umat Allah atau Gereja hadir di tengah-tengah masyarakat dan menata kehidupan bersama. Alkitab dapat membantu kita memahami kehendak Allah dalam pengelolaan kehidupan politik tetapi tidak menyangkut detail keterlibatan dalam politik praktis. Dalam Alkitab ditemui berbagai hal yang didalamnya mengajak umat untuk turut serta dalam pembangunan bahkan dalam pemerintah. Melalui nabi yeremia, mengajarkan agar setiap orang turut bertanggungjawab 
untuk membangun kesejahteraan kota di mana ia ditempatkan oleh Tuhan (Yer. 29:4-7 ; Rm. 13:17). Bila hal seperti ini berlaku dalam masa dan terhadap pemerintah yang sedang menjajah apalagi terhadap pemerintah bangsa Indonesia. Pemerintah Publik Indonesia adalah pemerintah kita sendiri dan kehadiran kita pada saat seperti ini di tengah Republik ini adalah ketetapan Tuhan, bukan atas pilihan kita sendiri karena itu harus kita terima dan syukuri dengan demikian dapat di garis bawahi pemerintah itu adalah Ketetapan Tuhan, bukan atas pilihan kita. Sama seperti bagian komponen bangsa yang lain, umat kristiani baik secara individu maupun kelompok ikut bertanggung jawab untuk menjaga kelangsungan kemerdekaan bangsa ini dalam arrti bebas dari pengaruh dan kekuatan luar manapun dan memaksanya untuk melakukan apa yang sesungguhnya tidak di inginkan. Maka umat yang mengemban tugas bersama untuk turut serta mewujudkan cita-cita yang terkandung dalam Pancasila. Yesus sendiri adalah seorang aktivitis dan pembaharu politik. Walaupun Yesus tidak pernah membentuk Gereja atau partai politik, tetapi Yesus aktif melakukan gerakan moral untuk membaharui, memperbaiki, bahkan dengan cara-cara damai Dia pernah menggoyangkan kemapanan dan status quo pada samannya. Selama hidup dan pelayanan di dunia ini, tiga setengah tahun, Dia berjuang tanpa rasa takut menentang penjajahan Romawi dan pemerintahan "Boneka" Romawi yakni Sanhedrin dan Imam Kepala yang diberikan wewenang terbatas memerintah Yahudi di Palestina ${ }^{5}$ Dan demikian halnya dalam masalah pajak, ketika Yesus ditanya tentang pajak kepada Kaisar (negara), Dia mengatakan prinsip pemisahan Gereja dengan Negara. Berikanlah kepada Allah yang wajib kamu berikan kepada Allah (Mat.22:21). Pengajaran ini juga dijadikan untuk menjerat Yesus. ${ }^{6}$ Dalam prinsip etika politik Alkitabiah, suatu pemerintahan yang baik memang terfokus dalam ketiga urusan ini: penegakan hukum yang tidak berat sebelah, keadilan bagi orang miskin, dan pembebasan warga dari penindasan dan kekerasan. Syair mazmur-mazmur yang terkait dengan peran kekuasaan berulang-ulang mengungkapkan pemerintahan ideal adalah yang menyahuti seruan orang berkekurangan, yang peduli orang miskin, dan yang menentang kekerasan melainkan mengupayakan damai. Di balik etika itu terdapat pengakuan bahwa para penguasa yang memihak pada pemulihan kaum yang lemah, miskin dan tertindas adalah "wakil” Allah. Jadi dapat dikatakan bahwa dalam Perjanjian Lama yang menetukan sistem perpolitikan, khususnya di kalangan bangsa Israel dalam menata kehidupan bersama adalah ketaatan kepada Allah yang ditandai dengan berlakunya hukum Taurat dan keadilan. Ada beberapa aspek dari kehidupan yang menonjol dalam pengajaran dan kehidupan Yesus Kristus yakni hubungan dan perhatian-Nya terhadap rakyat jelata atau miskin dan termarginalkan. Jika kita menelusuri latar belakang kehidupan Yesus maka Dia sebenarnya berasal dari kalangan rakyat kecil dan melakukan pemberitaan dan pelayanannya terutama di wilayah pedalaman Galilea di antara rakyat kecil. Laporan Injil-injil mengenai pekerjaan dan pengajaran

\footnotetext{
5 Ibid, hal 12

${ }^{6}$ Ibid
} 
Yesus memperlihatkan perhatian terhadap dan keakrabanya dengan dunia orang kebanyakan. Ia berbelas kasihan terhadap orang banyak (Mat. 9:36). Orang-orang yang dilayani Yesus secara langsung adalah rakyat miskin dan mereka yang dikucilkan dari masyarakat. Penyembuhanpenyembuhan-Nya adalah atas rakyat kecil yang sakit seperti orang buta dan orang timpang. Ia memberi makan kepada orang banyak, yaitu rakyat yang datang berkumpul mendengar pengajarannya tanpa bekal yang cukup. Pengajaran Yesus Kristus sendiri memihak kaum jelata. Sabda bahagia dalam khotbah di bukit (Luk. 6:20-21) tertuju kepada mereka: "Berbahagialah, hai kamu yang miskin, karena kamulah yang empunya Kerajaan Allah. Berbahagialah, hai kamu yang sekarang ini lapar, karena kamu akan dipuaskan. Berbahagialah hai kamu yang sekarang ini menangis karena kamu akan tertawa (Luk. 6:20-21; Mat. 5:1-2). Pengajaran Yesus Kristus bertolak dari pemahaman akan misinya selaku Mesias pembawa kabar sukacita bagi kaum miskin dan menderita. Dalam khotbah-Nya di Nazaret, Yesus merujuk kepada nubuatan nabi Yesaya (Yes. 61:1-2): "Roh Tuhan ada pada-Ku, oleh sebab ia mengurapi aku, untuk menyampaikan kabar baik kepada orangorang miskin; dan Ia telah mengutus Aku dan memberitakan pembebasan kepada orang-orang tawanan, dan penglihatan bagi orang-orang buta, untuk membebaskan orang-orang yang tertindas, untuk memberitakan tahun rahmat Tuhan telah datang" (Luk. 4:18-19). Mesias dikaruniakan dan diperlengkapi Tuhan dengan kemampuan untuk mengatasi krisis yang melanda masyarakat, tugas mesias adalah menegakkan keadilan bagi rakyat yang tertindas, dan memulihkan damai sejahtera di tengah-tengah masyarakat, serta membawa umat pada pertobatan, mesias bekerja tidak terutama dengan mengandalkan kekuatan kekuasaan, melainkan dengan kerelaan untuk menderita. ${ }^{7}$

\section{Hubungan Gereja dan Negara.}

Istilah Gereja berasal dari bahasa latin ecclesia dan berasal dari bahasa Yunani ekklesia . Dan kata ini tertulis dalam Perjanjian Baru; misalnya diterjemahkan dengan kata orang atau jemaat (dahulu diterjemahkan dengan kata "sidang" ataupun "sidang jemaat"); jemaat dari segala tempat dan segala abad, persekutuan segala orang percaya; sering juga disebut gereja yang tidak kelihatan (Mat. 16:18); jemaat di suatu kota (Kis 5:11); jemaat yang berkumpul di sebuah rumah (Rm 16:5). ${ }^{8}$ Sedangkan Negara merupakan sebuah organisasi tertinggi yang mempunyai kekuasaan untuk mengatur sesuatu yang berhubungan dengan kepentingan masyarakat umum. Negara juga memiliki peran untuk melindungi setiap penduduknya dan mencerdaskan dengan mensejahteraan kehidupan warganya. Hubungan antara Gereja dan Negara merupakan hal yang sangat penting dibicarakan baik dalam lingkup akademis maupun dalam lingkup masyarakat pada umumnya. Hubungan itu berbeda dari waktu ke waktu seiring dengan hubungan antara keduanya menimbulkan polemik. Di Indonesia

\footnotetext{
${ }^{7}$ Zakaria J. Ngelow, Gereja dan Masyarakat Madani di Indonesia, Jurnal Teologi Persetia, 1999, Hlm. 32-33

${ }^{8}$ R. Soedarmo, Kamus Istilah Teologi, Jakarta: BPK Gunung Mulia, 2002, hlm, 30.
} 
khususnya pada zaman kolonial, kita juga menghadapi kasus yang serupa. Pemerintah kolonial Belanda antara lain menempatkan apa yang disebutnya“Commisarissen” di dalam majelis-majelis Jemaat 'De Indische Kerk', yang pada waktu itu merupakan Gereja-Negara, yang berfungsi sebagai yang mewakili kepentingan-kepentingan Negara ${ }^{9}$

Philip Wogaman, guru besar Etika Kristen di Wesley Theological Seminary, Washington, Amerika Serikat (AS) menulis buku berjudul Christian Perspectives on Politics (2000) membedakan empat tipe hubungan negara dan agama:

1. Pertama, Teokrasi, yaitu suatu kehidupan bernegara yang di dalamnya pemimpin agama atau lembaga keagamaan tertentu mengendalikan kehidupan bernegera lewat berbagai kebijakan kenegaraan dan undang-undang untuk tujuan-tujuan agama tersebut di mana negara berada di bawah kontrol pemimpin-pemimpin agama. Dalam masyarakat primitif, bentuk negara seperti ini sangat lazim, seperti di dalam teokrasi Ibrani kuno.

2. Kedua, Erastianisme. Istilah ini berasal dari nama seorang Swiss-Jerman di abad ke-16, Thomas Erastus. Di sini negara, atau lebih tepat para politisi berusaha mengendalikan gereja. Mereka mencari keuntungan-keuntungan politik dengan memperalat gereja. Singkatnya, gereja dipolitisasi bagi keuntungan-keuntungan politik. Bentuk erastianisme memiliki kemiripan dengan bentuk Gereja-Negara. Yang dimaksud dengan Gereja-Negara adalah kehidupan bersama dalam suatu Negara (state nation) dimana pemerintah memberi jaminan keamanan atau perlindungan istimewa bagi gereja atau agama tertentu. Negara menjalankan pengawasan yang ketat dan memiliki wibawa yang besar dalam kehidupan sosial termasuk kehidupan beragama, Negara mengatur semua hal termasuk agama mana yang harus dianut oleh wargannya. Dalam Gereja-Negara bisa juga ditemukan agama lain, tetapi eksistensi agama itu dan hak-hak pemeluk agama ini sangat tidak menentu. Masih beruntung jika agama mereka tidak dipedulikan. Yang paling celaka ialah jika agama itu dan pemeluknya dianiya dan ditindas oleh penguasa. Ini yang terjadi dengan keadaan agama Kristen pada periode awal berdirinya 10

3. Ketiga, pemisahan gereja dan negara secara ramah adalah suatu kehidupan bernegara yang di dalamnya ada pemisahan yang tegas secara legal antara kehidupan beragama dan

\footnotetext{
${ }^{9}$ Carlton Clymer Rodee dkk (ed), op.cit, hlm. 3

${ }^{10}$ Ebenhaizer I. Nuban Timo, Umat Allah di Tapal Batas: Percakapan Tentang Gereja Jilid II: Masa Kini Gereja, dicetak oleh Alfa Design Kemiri II - Salatiga, 2011, hlm. 295.
} 
kehidupan bernegara. Di banyak negara pemisahan itu berlaku secara legal, tanpa kekerasan dan rasa benci. Itulah yang secara konstitusional terjadi di Amerika Serikat, kendati di dalam kenyataannya tidak selalu begitu.

4. Keempat, pemisahan gereja dan negara yang tidak ramah. Khususnya dalam dua abad terakhir pemisahan seperti ini marak. Gerakan anti-klerikalisme (anti-gereja) misalnya di Perancis pada abad ke-19. Juga di Mexico terjadi hal serupa, ketika para imam dilarang memakai pakaian imam. Di kebanyakan negeri Marxis juga pemisahan seperti ini terjadi. Negara Albania dulu merupakan contoh yang sangat jelas bahwa negara sama sekali tidak mau tahu dengan gereja.

Hak independensi ini ada pada setiap individu dan masyarakat sebagai bagian dari hak-hak asasinya. Hak ini bukan pemberian Negara, walaupun Negara seharusnya menjamin hak-hak individu dan masyarakat untuk bersikap untuk bersikap sesuai dengan hati nurani dan keyakinannya, selama itu tidak menimbulkan anarki. Dalam arti Negara harus menjamin kebebasan beragama. Tetapi dijamin atau tidak oleh Negara, gereja wajib untuk mewujudkan kebebasannya itu, dan jika perlu bersedia menderita demi suara hati nurani dan keyakinannya.

Dengan melihat pemahaman gereja dan negara, jelas ada hubungannya karena sama-sama menyinggung masyarakat dimana di dalam gereja, masyarakat digambarkan sebagai jemaat. Dengan demikian bahwa gereja dengan negara sudah pasti memiliki hubungan yang sangat berkaitan satu dengan yang lainnya. Demikian halnya Gereja dan Negara pasti memiliki hukum, karena dalam penegakan hukum ada dua komponen yang saling terkait yaitu orang (gereja) dan system (hukum) “ bad system destroys good people; bad people destroys good systems”. Hukum yang jelek merusak manusia yang baik, manusia yang jelek merusak hukum yang baik. ${ }^{11}$ Melalui kehadiran gereja (orang) akan sangat menentukan perkembangan serta kesejahteraan suatu bangsa. Kehadiran gereja sebagai salah satu cara menyampaikan kebenaran kepada para penguasa pemerintah dalam menjalankan tugasnya dengan benar. Karena negara merupakan suatu bidang kehidupan dimana Gereja dapat memperjuangkan terwujudnya tanda-tanda kerajaan Allah di dalam Yesus Kristus seperti keadilan, kebenaran, damai sejahtera dan sebagainya. ${ }^{12}$ Gereja juga dipahami sebagai komunitas iman kepada Yesus Kristus atau bisa disebut juga komunitas iman politis. ${ }^{13}$ Karena itu, kalau Gereja ingin mengabdi kepada Allah dalam Yesus Kristus, maka Gereja juga harus bersifat politis. Tetapi memang

\footnotetext{
${ }^{11}$ Daulay, Richard, Kekristenan dan Politik. Jakarta: Waskita Publishing, 2013, hal 9

${ }^{12}$ Sairin, Weinata- Patiassina, J.M. (Peny), Hubungan Gereja dan Negara dan Hak-Hak Asasi Manusia, Jakarta, BPK Gunung Mulia, 1996

${ }^{13}$ Singgih, Emanuel Gerrit, Iman dan Politik Dalam Era Reformasi di Indonesia, Jakarta, BPK Gunung Mulia, 2004.
} 
harus ditegaskan bahwa kehadiran dan peran Gereja di bidang politik harus dibedakan secara prinsip, hakikat, sifat dan bentuk dari partai politik. Karena Gereja bukanlah partai politik dan tidak sama dengan partai politik. ${ }^{14}$ Gereja memiliki tugas panggilan yakni untuk memberikan bimbingan bimbingan pastoral, turut dalam terselenggaranya suatu kehidupan politik yang benar, adil dan mendatangkan damai sejahtera bagi semua orang. Gereja pun harus terbuka, dinamis, dialogis pada situasi perkembangan di masyarakat dengan sikap positif, kritis, kreatif dan realistis ${ }^{15}$ Gereja harus menegakkan kebenaran di tengah kehidupan politik, yaitu menegakkan keadilan dan mewujudkan kasih. Maka kekuasaan politik dalam negara harus diarahkan untuk mewujudkan keadilan dan cinta kasih dengan kata lain, tujuan keterlibatan gereja dalam politik agar manusia lebih taat kepada Allah, dari pada manusia ${ }^{16}$ Gereja harus dapat menjadi pengkritik atau pengamat politik apabila pemerintah tidak menjalankan tugasnya dengan benar sesuai dengan perundang-undangan yang sudah disepakati sebagai dasar dalam sistem pemerintahan di Indonesia. Dalam kaitan ini gereja diharapkan dapat memiliki prinsip yang Alkitabiah sehingga tidak terpengaruh dalam penyimpangan-penyimpangan yang disebabkan oleh orang yang tak bertanggunjawab seperti, korupsi, penindasan dan kekerasan lainnya. Gereja-gereja di Indonesia harus menjadikan ini sebagai salah satu bentuk tindakan nyata gereja dalam bidang politik dan perlu kita ketahui bersama bahwa politik juga bagian dari ladang pelayanan yang harus kita layani. Dalam Perjanjian Lama Yer. 29:7 mengatakan agar umat Israel yang terbuang ke Babel supaya mengusahakan kesejahteraan kota di mana mereka di buang. Mereka dinasehati untuk menyerahkan kota tersebut kepada Tuhan karena kesejahteraan kota itu juga merupakan kesejahteraan bangsa Israel. Disini sangat terlihat adanya hubungan antara kota dimana mereka dibuang, kesejahteraan kota merupakan kesejahteraan warganya terdiri akan umat Allah, jadi umat Allah akan berperan aktif dalam mensejahterakan kota tersebut. Sebagai orang Kristen yang tinggal di Indonesia kita juga memiliki tanggung jawab sebagai warga negara. Dalam hal ini kita memiliki dua kewarganegaraan yaitu warga negara kerajaan Allah ( 1 Yoh. 3:16) dan lalu kita diutus ke dunia Indonesia sehingga kita menjadi warga negara Indonesia. Oleh karena itu, kita disuruh Allah untuk berdoa demi kebaikan Indonesia (1 Tim. 2:1-2, Yes. 2:27). Sebagai orang Kristen kita harus menjadi garam dan terang di tengah - tengah masyarakat dan negara kita. Dengan sikap dan ketaatan kita kepada pemerintah sebagai warga negara yang baik merupakan tanggung jawab kita kepada Tuhan. Ketaatan kita kepada pemerintah adalah dalam rangka ketaatan kita kepada Allah (Kis. 5:29).

\footnotetext{
${ }^{14}$ Sibarani, Poltak.YP. 2004. Bolehkah Gereja Berpolitik (Mencari pola hubungan Gereja dan Negara yang relevan di Indonesia). Jakarta: Ramos Gospel Publishing House.

15 Borrong, Robert P. 2006. Etika Politik Kristen,serba-serbi politik praktis. Jakarta: Unit Publikasi dan Informasi STT Jakarta.

16 Ibid
} 
Paulus menekankan bahwa orang Kristen tidak boleh menjungkirbalikkan system atau melarikan diri dari system yang ada. Orang Kristen harus tetap ada dalam system itu, sehingga orang Kristen bisa mentransformasi system itu atas dasar dan kekuatan iman Kristen itu sendiri. Itulah sebabnya Paulus mengatakan: "tiap-tiap orang harus takluk kepada pemerintah yang diatasnya...(Roma 13:1a) ${ }^{17}$ Jadeni menurut Paulus, negara adalah institusi ilahi (a divine institution) dengan kuasa yang datang dari Allah.

\section{Etika Politik Dalam Perspektif Kristen}

Etika dan moral Kristen adalah ajaran yang mengandung nilai-nilai etika dan dapat menjadi paduan bagi kehidupan individu maupun kelompok yang aktif dalam bidang politik sesuai dengan keyakinan Kristiani. Setiap orang yang telah menjadi anggota gereja di Indonesia adalah penduduk Indonesia yang dilindungi oleh pemerintah negara Indonesia, bergantung kepada pemerintah negara Indonesia. Sehingga dengan demikian orang Kristen yang merupakan anggota masyarakat dan penduduk negara Indonesia punya hak dan kewajiban serta tanggung jawab yang sama seperti penduduk lainnya. Sebagai orang beriman percaya bahwa pemerintah suatu negara dipakai Allah sebagai wakil-Nya di dunia untuk menata kehidupan masyarakat. Hal ini sesuai dengan apa yang telah dijelaskan dan diterangkan oleh penulis surat Roma 13:1-7. Oleh sebab itu dikatakan bahwa Kepedulian terhadap kehidupan bersama negarawi merupakan tanggung jawab yang tidak dapat diabaikan oleh orang Kristen/gereja. Kristus bukannya tidak peduli akan kemiskinan, korupsi, dan ketidakadilan. Alkitab memperlihatkan bahwa Ia sangat prihatin dengan keadaan yang mengenaskan di sekitarnya. (Markus 6:33, 34). Maka diperlukan peran etika dan moral kristen dalam kehidupan berbangsa dan bernegara. Melihat perkembangan terkini, sikap politik orang Kristen dapat di bagi menjadi tiga kelompok:

1. Apolitik. Tidak dapat dipungkiri bahwa ada kesenjangan antara gereja atau orang Kristen dengan negara dewasa ini. Kesenjangan yang terjadi antara orang Kristen dengan negara dapat dilihat dari adanya sebagian jemaat Kristen yang anti pemerintah/negara (Apolitis), politik dianggap kotor, dan pemerintah dianggap mendiskreditkan gereja/orang Kristen. Gereja dan warga Kristen di Indonesia yang meninggalkan persepsi (warisan Pietisme) ini, namun dalam batas tertentu masih banyak warga yang menganut pandangan yang demikian. Masih banyak pemimpin dan warga gereja yang Apolitik. Walau gereja bukanlah kekuatan politik, tetapi kekuatan moral namun sikap apolitik terlalu ekstrim ${ }^{18}$

2. Perebut Kekuasaan. Suatu kelompok yang ingin merebut kekuasaan politik atau paling sedikit mempunyai kekuatan signifikan dalam bentuk struktur pemerintahan agar dapat menentukan

\footnotetext{
${ }^{17}$ Daulay, Richard, Kekristenan dan Politik. Jakarta: Waskita Publishing, 2013, hal 9

18 Ibid
} 
jalannya negeri ini. Sikap seperti ini lahir dari pengalaman pahit penganut pandangan dimana orang Kristen di Indonesia dianggap sedang di marginalkan bahkan dianiaya. Untuk membela nasib orang Kristen di Indonesia penganut pandangan ini "Bermimpi" untuk masuk dalam struktur kekuasaan dalam rangka menentukan arah pemerintahan.

3. Alat Kristus. Orang Kristen di Indonesia terpanggil sebagai garam dan terang dunia yang melalui iman Kristianinya dapat melakukan transformasi politik secara positif, kritis, kreatif,dan realistis.

Gereja atau umat Kristen tidak diperkenankan membiarkan kekuasaan duniawi berkembang ke arah yang cenderung destruktif. Dengan demikian etika kristen sangat perlu dalam dunia politik, Robert P Borong dalam bukunya yang berjudul "Etika Politik Kristen,serba-serbi politik praktis" mengapa pentingnya Etika Kristen dalam politik karena:

a. Allah melalui Firman-Nya selalu mengajarkan dan mengkehendaki yang baik dan benar dalam kehidupan manusia, termasuk kehidupan bermasyarakat dan bernegara supaya ada kedamaian dan kesejahteraan lahir batin.

b. Politik adalah kegiatan yang bertujuan untuk kebaikan dan kebenaran dalam kehidupan bermasyarakat dan bernegara. Politik tidak bertujuan untuk mencapai kepentingan sendiri atau kelompok saja, melainkan dan terutama kepentingan bersama sebagai bangsa

c. Para pelaku politik adalah orang-orang yang menerima kuasa dan wibawa dari Tuhan untuk menegakkan kebaikan dan kebenaran.

d. Para politisi adalah manusia "berdosa" penuh kekurangan bahkan cenderung kepada kejahatan (Destruktif) sehingga memerlukan paduan, arahan dan norma dari agama.

e. Kegiatan politik adalah juga misi Allah (misio Dei) yang bertujuan mewujudkan kekuasaan dan kedaulatan Allah di dunia.

\section{Tindakan Praktis Etika Kristen Terhadap Politik}

Tindakan praktis gereja terhadap politik adalah segala upaya dan suatu proses untuk memahami dan cara memaknai relitas politik dari cara pandang dan cara berpikir yang telah diajarkan dalam Alkitab. Mengupayakan suatu kesejahteraan kota dalam hal ini dimaksud dengan politik merupakan suatu amanat yang dituliskan Alkitab untuk seluruh umat Tuhan

\section{a. Positif}

Tugas utama dari gereja adalah menegakkan ajaran etika atau moral (termasuk etika berpolitik) menyuarakan kebenaran dan mengoreksi yang salah. Karena itu gereja harus membina tabiat 
anggota-angggotanya serta menjadi persekutuan yang mendukung moralitas mereka ${ }^{19}$ Inilah yang biasanya disebut sebagai suara kenabian gereja. Hidup berbangsa dan bernegara merupakan hal penting untuk berpartisipasi dan menjunjung tinggi program dan kegiatan pemerintah negara. Dalam hal ini diperlukan kesadaran untuk menunjukan integrasi antara masyarakat dengan pemerintah. Orang Kristen pun ambil bagian karena orang Kristen merupakan bagian dari negara yang disahkan secara hukum dan undang-undang negara Republik Indonsia.Sebagai warga negara yang baik, kita harus mampu menerapkan sikap positif terhadap Pancasila dalam kehidupan bukan malah membuat atau berperilaku yang merugikan negara atau orang. sikap positif terhadap Pancasila dalam lingkungan berbangsa dan bernegara misalnya melaksanakan kewajiban sebagai warga negara, membayar pajak, ikut menjaga keharmonisan hidup, tidak melakukan tindakan kriminal, mentaati peraturan yang berlaku. Dengan demikian gereja bukanlah untuk berjuang agar tatanan sosial menjadi sepadan dengan visinya sendiri melainkan menyajikan visi pengharapan yang benar kepada masyarakat ${ }^{20}$ Yesus Kristus bukan hanya menjadi pembebas dan pendamai bagi mereka yang mengikuti-Nya tetapi Ia pun menjadi teladan bagi mereka ${ }^{21}$

\section{b. Kritis}

Pertama-tama Gereja harus kritis terhadap dirinya sendiri dan tidak memutlakkan agama. Gereja bukanlah Kerajaan Allah, dan pandangan Gereja bukan wahyu. Gereja hanya dapat menyampaikan pandangannya mengenai manusia dan masyarakat dalam ketaatan kepada sabda Allah, yang senantiasa harus direnungkan, dan mengakui bahwa "semua berbuat dosa dan kehilangan kemuliaan Allah" (Rm 3:23). Bahkan, "jika kita berkata, bahwa tidak mempunyai dosa, maka kita menipu diri sendiri dan kebenaran tidak ada di dalam kita" (1Yoh 1:8). Gereja sendiri tidak sempurna, pewartaan serta pandangannya juga banyak kekurangannya. Dengan rendah hati Gereja boleh menyampaikan pandangannya sambil mendengarkan orang lain, sebab dunia berkembang dan masalah sosial berubah. Karena itu kehadiran dan keterlibatan kita dalam politik tidak sekedar ikut serta menjadi pengembira melainkan pemeran yang berkewajiban memberikan penilaian yang normatif.

Melawan ideologi dengan ideologi tidak ada gunanya. Kalau dimutlakkan, agama juga dapat menjadi ideologi dan alat politik melulu. Justru sikap pelayanan harus menjaga Gereja supaya tetap mempertahankan sifat keagamaannya sebagai komunikasi iman. Sebagai lembaga

\footnotetext{
${ }^{19}$ Brownlee Malcolm, Pengambilan Keputusan Etis dan faktor-faktor di dalamnya, Jakarta : BPK Gunung Mulia, 2009. Hal.164

${ }^{20}$ Gaylord Noyce, Tanggungjawab Etis pelayan Jemaat, Jakarta:BPK Gunung Mulia, 2002. Hal. 154

${ }^{21}$ J. Verkuyl, Etika Kristen Bagian Umum, Jakarta:BPK Gunung Mulia,2002, hal. 206
} 
keagamaan di dalam masyarakat, secara tidak langsung ada bahaya bahwa Gereja mengikuti arus masyarakat saja, sehingga tidak lagi dapat mewartakan Injil serta memberi kesaksian mengenai imannya sendiri. Supaya tetap setia kepada Kristus dan sikap pelayanan-Nya, Gereja harus terusmenerus merenungkan dasar-dasar iman, dan tidak terlampau percaya pada ajaran serta organisasinya sendiri. Juga sebagai organisasi, Gereja harus tampil di dalam masyarakat sebagai pewarta sikap dan pandangan Kristus serta bukan mewartakan pandangannya sendiri. "Bukan diri kami yang kami beritakan, tetapi Yesus Kristus sebagai Tuhan, dan diri kami sebagai hamba, karena kehendak Yesus" (2Kor 4:5). Gereja tidak meneruskan ajaran baku yang sudah membeku, melainkan atas dasar iman dan sikap pelayanan, senantiasa ikut mencari jalan hidup, bersama dengan orang lain.

\section{c. Kreatif}

Sikap yang kreatif adalah suatu kemampuan yang mencerminkan kelancaran, keluwesan, dan orisinalitas dalam berpikir serta kemampuan untuk mengelaborasi suatu gagasan. Kreatif yang ada pada individu digunakan untuk menghadapi berbagai permasalahan yang ada ketika berinteraksi dengan lingkungannya dan mencari berbagai alternatif pemecahannya sehingga dapat tercapai penyesuaian diri yang baik. Seiring dengan perkembangan zaman, kita harus mampu menciptakan dan mengembangkan sikap kreatif dan inovatif, karena dengan sikap kreatif dan inovatif tersebut kita dapat memajukan kesejahteraan dan kemakmuran bangsa pada umumnya. Sebagai umat kristen hendaknya juga menjadi agen-agen perubahan yang kreatif untuk itu dibutuhkan keteladanan sikap perilaku yang baik. Setiap umat kristen yang terlibat dalam politik harus berani mengatakan "Tidak" atas semua tawaran, bujukan, atau strategistrategi yang dapat membuat jatuh pada tindak korupsi, kolusi ataupun nepotisme serta menjauhi segala bentuk premanisme. Oleh karena itu yang harus dikembangkan adalah solidaritas kritis dalam proses emansipasi sosial-politik di mana semua pihak bisa menciptakan suatu suasana terbuka dan memberi sumbangan dialogis terhadap masalah-masalah dasar masyarakat. Sebagai orang beriman percaya bahwa pemerintah suatu negara dipakai Allah sebagai wakil-Nya di dunia untuk menata kehidupan masyarakat. Hal ini sesuai dengan apa yang telah dijelaskan dan diterangkan oleh penulis surat Roma 13:1-7. oleh sebab itu dikatakan bahwa Kepedulian terhadap kehidupan bersama negarawi merupakan tanggung jawab yang tidak dapat diabaikan oleh orang Kristen.

\section{d. Realistis}

Perlu diingat kembali bahwa Indonesia memiliki lebih dari 1000 suku dan banyak ras. Begitupun dalam masyarakat, tentunya terdapat beraneka ragam suku, ras, agama, dan lainnya. 
Keberagaman ini seharusnya bukanlah sesuatu yang dapat mengkotakkan masyarakat. Seperti semboyan negeri Indonesia "Bhineka Tunggal Ika", berbeda-beda namun tetap satu jua. Pesan dari semboyan ini adalah kita harus lebih mengutamakan persamaan kita sebagai sesama masyarakat. Fungsi toleransi dalam kehidupan adalah hal yang sangat kental dalam negara demokrasi. Dengannya, persatuan dalam masyarakat tidak mudah tercerai berai. Sebagai manusia biasa, tentunya kita ingin dihormati oleh orang lain. Namun, semua manusia pun mengharapkan hal yang sama, sehingga berlaku sebuah hukum, yaitu siapa yang hendak dihormati haruslah menghormati orang lain terlebih dahulu. Dasar dari demokrasi adalah rakyat punya hak setara, maka sudah menjadi kewajiban bagi masyarakat penganut paham demokrasi bahwa ia harus menghormati antar anggota masyarakat, toleransi juga harus ditegakkan. Sebagai orang Kristen harus mengingat bahwa tujuan gereja bukan mengasingkan orang dari dunia. Gereja harus memperlengkapi anggotanya agar dapat melayani dalam dunia. Kekuatan moral dan nilai-nilai yang diterima dalam gereja dapat menjadi bekal bagi kehidupan sehari-hari. Tanggungjawab Kristen tidak terbatas pada saudara-saudara seiman melainkan semua orang yang ada dalam dunia ini. Seorang manusia Kristen tidak hidup dalam dirinya sendiri, tetapi ia hidup di dalam Kristus dan sesamanya manusia 22

\section{Kesimpulan}

Meskipun kondisi perpolitikan di Indonesia sering mengalami perdebatan yang memanas akibat relasi yang kurang baik di antar penganut tertentu. Namun perlu kita tetap pertahankan adalah Negara Indonesia adalah negara Kesatuan dalam Bhineka Tunggal Ika. Karna masa depan bangsa Indonesia sangat bergantung pada sejauh mana bangsa Indonesia yang sangat majemuk ini dapat membangun kebersamaan melalui terwujudnya persaudaraan dalam segala bidang di bangsa ini. Gereja harus ada dalam proses perumusan kebijakan pemerintah. Gereja harus aktif mempengaruhi kebijakan negara melalui politik. Gereja tidak bisa menarik diri atau diam terhadap proses politik. "The church has to be prophetic, speaking for God. The church has to herald the ethical values that enrich a nation. The church has to be bold and forthright, constructive and innovative. The church has to be "salt and light" in what is so often a corrupt environment, to bring light and health. Dalam dunia politik dan hukum, sikap gereja yang perlu dikembangkan adalah sikap positif, kritis, dan kreatif. Positif artinya memandang dunia politik sebagai bidang pengabdian dan ladang pelayanan dari Tuhan serta memiliki pandangan positif ketika memberikan kontribusi sesuai iman Kristen. Kritis artinya tidak ragu-ragu dalam memberikan kritik jika penguasa berbuat kesalahan, menyimpang dari hukum dan prinsip-prinsip yang berlaku. Kritik yang sesuai dengan etika Kristen adalah kritik

\footnotetext{
22 J. Verkuyl, Etika Kristen Bagian Umum, Jakarta:BPK Gunung Mulia,2002, hal. 216
} 
yang konstruktif dan membangun, santun, dan memperdayakan, bukan kritik yang destruktif dan menjatuhkan, Fulgar, dan mencari kesalahan. Kreatif artinya berusaha memberikan terobosan atau alternatif baru di tengah kebuntuan terhadap politik. Kita harus mampu berkomunikasi terbuka dan dialogis, tidak alergi terhadap perubahan. Gereja harus memberitakan nilai-nilai etika yang memperkaya bangsa. Gereja harus berani dan tegas, konstruktif dan inovatif. Dan yang tak kalah penting adalah gereja-gereja di Indonesia harus mampu meningkatkan dan memperkokoh keesaan gereja sebagai utusan Allah, dengan demikian gereja-gereja di Indonesia tidak semakin larut dalam perpecahan yang dapat menjadi potensi lemahnya peran dan fungsi gereja ditengah politik di bangsa ini. Maka sebagai orang percaya kita harus selalu mendahulukan kepentingan umum daripada kepentingan pribadi, kepentingan golongannya atau kepentingan partainya. Dalam prinsip itu langsung terimplikasi, bahwa politisi Kristiani tidak boleh ikut korupsi (waktu, uang, tenaga). Politisi Kristiani berpolitik demi kesejahteraan masyarakat dan tidak memakai kesempatan yang ada, untuk memperkaya diri. Karena Peranan umat Kristen dalam kancah politik adalah menjadi garam dan terang dunia (Matius 5 : 13-14). Di samping itu, gereja berperan sebagai salah satu institusi keagamaan yang mengawali dan melestarikan sikap kritis jika suatu gereja itu hendak eksis sebagai pelayan yang menggarami dan menerangi dunia ini

Saran :

1. Sebagai utusan Allah, Gereja juga perlu terlibat dalam politik dan hukum, dalam arti yang luas mengikuti dengan seksama berbagai perkembangan politik di Indonesia.

2. Gereja wajib dalam menggunakan suaranya dalam pemilihan umum yang diadakan di tengah bangsa ini.

3. Gereja perlu melakukan pertemuan konsultatif secara berkala dengan anggotaanggota jemaatnya yang terlibat dalam politik dan hukum praktis.

4. Gereja perlu menyelenggarakan pembinaan ataupun seminar yang membahas tentang tindakan etika Kristen dalam politik, sehingga pemahaman salah yang dimiliki oleh anggota dapat dipatahkan dengan memperdalam kehidupan politik dan hukum sesuai kapasitas dan kemampuaannya. Melalui itu diharapkan dapat membentuk moral atau etika umat Kristen ketika berhadapan dengan kehidupan politik. 


\section{KEPUSTAKAAN}

1. Borrong, Robert P. Etika Politik Kristen,serba-serbi politik praktis. Jakarta: Unit Publikasi dan Informasi STT Jakarta, 2006

2. Brownlee Malcolm, Pengambilan Keputusan Etis dan faktor-faktor di dalamnya, Jakarta : BPK Gunung Mulia, 2009.

3. Daulay, Richard, Kekristenan dan Politik. Jakarta: Waskita Publishing, 2013

4. Ebenhaizer I. Nuban Timo, Umat Allah di Tapal Batas: Percakapan Tentang Gereja Jilid II: Masa Kini Gereja, dicetak oleh Alfa Design Kemiri II - Salatiga, 2011

5. Gaylord Noyce, Tanggungjawab Etis pelayan Jemaat, Jakarta:BPK Gunung Mulia, 2002.

6. Gunche Lugo, Manifesto Politik Yesus, Yogyakarta: Penerbit ANDI, 2009

7. J. Philip Wogaman, Christian Perspective on Politics, Westminster John Knox Press, 2000.

8. Jim Haris, The Church's Role in Politics, The Big Picture, 1999 R. Soedarmo, Kamus Istilah Teologi, Jakarta: BPK Gunung Mulia, 2002 Carlton Clymer Rodee dkk (ed), op.cit,

9. Sairin, Weinata- Patiassina, J.M. (Peny), Hubungan Gereja dan Negara dan Hak-Hak Asasi Manusia, Jakarta, BPK Gunung Mulia. 2012

10. Sibarani, Poltak.YP. Bolehkah Gereja Berpolitik (Mencari pola hubungan Gereja dan Negara yang relevan di Indonesia). Jakarta: Ramos Gospel Publishing House. 2004

11. Singgih, Emanuel Gerrit, Iman dan Politik Dalam Era Reformasi di Indonesia, Jakarta, BPK Gunung Mulia, 2004.

12. Zakaria J. Ngelow, Gereja dan Masyarakat Madani di Indonesia, Jurnal Teologi Persetia, 1999.

\section{internet}

13. https://erixreview.wordpress.com/2013/09/02/tujuh-level-partisipasi-gereja-dalam-politik/

14. http://thebigpicture.homestead.com/ChurchinPolitics.html

15. http://www.ethos.org.au/site/Ethos/filesystem/documents/In-depth/Politics/Why-ShouldChristians-be-involved

16. http://repository.uksw.edu/bitstream/123456789/2972/3/T2_752011031_BAB\%20II 